\title{
Naupliar evolutionary novelties of Stenhelia peniculata (Copepoda, Harpacticoida) from Alaska affirming taxa belonging to different categorial rank
}

\author{
Hans-Uwe Dahms ${ }^{1}$, Nikolaos V. Schizas ${ }^{2}$, Thomas C. Shirley ${ }^{3}$ \\ ${ }^{1}$ Hong Kong University of Science and Technology (HKUST), Department of Biology, Coastal \\ Marine Lab (CML), Clear Water Bay, Hong Kong,SAR - China.e-mail: hansd@ust.hk \\ ${ }^{2}$ Department of Marine Sciences, University of Puerto Rico, Mayagüez Campus Isla Magueyes \\ Laboratories, P.O. Box 908, Lajas, PR 00667,Puerto Rico e-mail:n_schizas@cima.uprm.edu \\ ${ }^{3} J u n e a u$ Center, School of Fisheries \& Ocean Sciences, University of Alaska Fairbanks, 11120 \\ Glacier Hwy, Juneau, AK 99801, U.S.A. e-mail: Tom.Shirley@uaf.edu
}

ABSTRACT: All six naupliar stages of Stenhelia peniculata (Lang, 1965) from Auke Bay near Juneau (Alaska) are described. Naupliar morphology within the Stenheliinae differs among species and even more at supraspecific level. Nauplii of S. peniculata are characterized by the following apomorphies compared to the only other species of Stenhelia where nauplii have been studied, namely S. palustris ( $c f$. Dahms, Bresciani, 1993): third antennal segment bears three (S. peniculata) or two (S. palustris) medial setae at the third naupliar stage; mandibular endopod with three or four setae on outer lateral field at the sixth naupliar stage; no spinulation on mandibular exopod or strong spinulation; first maxilla with three or two setae. The nauplii of both these stenheliid species differ from those of Pseudostenhelia wellsi Coull, Fleeger, 1977 by the terminal seta of the first antenna, which is as long as the third segment (Stenhelia) or three times as long as the third segment (Pseudostenhelia); the four middle setae of the antennal endopod are of regular size (Stenhelia), instead of two of the four being much longer; the proximal seta of the mandibular exopod long instead of being short (Pseudostenhelia); their endopod having an outer lateral field with one long seta (Stenhelia) instead of having three long setae. A reaffirmation of the Stenheliinae Brady, 1880 is supported by the following stenheliinid apomorphies in the morphology of the nauplii (as evidenced from a comparison of Stenhelia and Pseudostenhelia, with all other oligoarthran harpacticoid nauplii as an outgroup): lateral edge of the naupliar shield bears protuberances on either side (Stenheliinae) instead of no protuberance (Oligoarthra); masticatory process of the second antenna is peculiarly fan-shaped distally (Stenheliinae) instead of tapering terminally (Oligoarthra); antennal exopod strongly developed, three-segmented and upwardly curved (Stenheliinae) instead of being four-segmented and never strongly developed (Oligoarthra); the whole mandible is of peculiar shape and orientation (Stenheliinae) instead of being common (Oligoarthra); the posterolateral field of the mandibular endopod bears a remarkable strong, inner spinulose spine (Stenheliinae) instead of lacking such spine (Oligoarthra); the three distal exopodal setae are of unique structure (Stenheliinae).

KEYWORDS: postembryonic development, morphology, key to stages, phylogeny. 


\title{
Эволюционные новообразования науплиусов Stenhelia peniculata (Copepoda, Harpacticoida) c Аляски, подтверждающие их таксономическую принадлежность к разным категориальным рангам
}

\author{
Г.-У. Дамс ${ }^{1}$, Николаус В. Шизас ${ }^{2}$, Томас К. Шерли ${ }^{3}$
}

${ }^{1}$ Hong Kong University of Science and Technology (HKUST), Department of Biology, Coastal Marine Lab (CML), Clear Water Bay, Hong Kong, SAR - China.e-mail: hansd@ust.hk

${ }^{2}$ Department of Marine Sciences, University of Puerto Rico, Mayagüez Campus Isla Magueyes Laboratories, P.O. Box 908,Lajas, PR 00667,Puerto Rico.e-mail: n_schizas@cima.uprm.edu

${ }^{3}$ Juneau Center, School of Fisheries \& Ocean Sciences, University of Alaska Fairbanks, 11120 Glacier Hwy,Juneau, AK 99801,U.S.A.e-mail:Tom.Shirley@uaf.edu

РЕЗЮМЕ: Все шесть науплиальных стадий Stenhelia peniculata (Lang, 1965) описаны по материалу, собранному недалеко от г. Джуно (Аляска, Auke Bay). Науплиусы Stenheliinae проявляют морфологические отличия на видовом и, в большей степени, на надвидовом уровнях. Науплиусы $S$. peniculata отличаются от таковых $S$. palustris (см. Dahms, Bresciani, 1993), другого вида Stenhelia, у которого изучены науплиальные стадии, следующими апоморфными признаками: третий сегмент антеннул науплиуса третьей стадии с тремя (S. peniculata) или двумя (S. palustris) медиальными щетинками; эндоподит мандибул шестой науплиусной стадии с тремя или четырьмя щетинками на наружном боковом крае; экзоподит мандибул без шипиков или с многочисленными шипиками; первые максиллы с тремя или двумя щетинками. Науплиусы двух видов стенхелиид отличаются от таковых Pseudostenhelia wellsi Coull, Fleeger, 1977 терминальной щетинкой первых антенн, длина которой равна длине третьего членика (Stenhelia) или превышает длину третьего членика в три раза (Pseudostenhelia); эндоподит антенн в средней части с четырьмя щетинками обычной длины (Stenhelia), а не с щетинками, две из которых значительно длиннее двух других щетинок; проксимальная щетинка экзоподита мандибул длинная, а не короткая (Pseudostenhelia); их эндоподит с одной длинной щетинкой на наружном боковом крае (Stenhelia), а не с тремя длинными щетинками. Монофилетичность Stenheliinae Brady, 1880 подтверждается следующими апоморфными морфологическими признаками науплиусов стенхелинид (выявленных в ходе сравнения науплиусов Stenhelia и Pseudostenhelia со всеми другими науплиусами олигоартных гарпактикоид, выбранных в качестве внешней группы): боковые края головного щита науплиусов с бугорками (Stenheliinae), а не без бугорков (Oligoarthra); жевательный вырост вторых антенн с веерообразной формой дистальной части (Stenheliinae), а не суживается терминально (Oligoarthra); экзоподит антенн хорошо развит, трехчленистый и изогнут вверх (Stenheliinae), а не слабо развит и четырехчленистый (Oligoarthra); мандибулы имеют специфическую форму и направление (Stenheliinae), а не наоборот (Oligoarthra); постеролатеральный край эндоподита мандибул с хорошо развитым шипом с шипиками на внутреннем крае (Stenheliinae), а не без такого шипа (Oligoarthra); три дистальных щетинки экзоподита необычной формы (Stenheliinae).

КЛЮЧЕВЫЕ СЛОВА: постэмбриональное развитие, морфология, определитель стадий, филогения. 


\section{Introduction}

In organisms with larval development, morphological characters in both early and late developmental stages, are phenotypes of the same genotype. However, when reconstructing phylogenetic relationships, adult characters are most often used, even though larvae provide a rich source of additional morphological, behavioural, and ecological as well as structural and developmental characters. Evidence from postembryonic stages should complement the data set from the adult organisation, for an individual exhibits different and significant characters at all phases of its ontogeny. Such characters could be used as species-specific character patterns of evolutionary species (Ax, 1987), as this has been shown for naupliar larvae of the Crustacea (Dahms, 2004a). Dahms (1990) demonstrated the usefulness of naupliar characters for phylogenetic considerations among the Harpacticoida and Walossek (1993) for Crustacea in general. Several other workers have used naupliar characters of copepods for phylogenetic considerations and their results will be discussed throughout this study.

Compared to other copepod taxa, the postembryonic development of harpacticoids is far less studied - despite Dahms's reviews for harpacticoid nauplii (1990) and copepodids (1993). Our lack of knowledge is exemplified in the large harpacticoid family Diosaccidae, comprising Diosaccinae, Stenheliinae and Miraciinae - the latter two hypothesized as sister-taxa by Willen (2000). All Stenheliinae and some taxa of the Diosaccinae develop nauplii, which are peculiarly shaped in relation to all other nauplii: these nauplii are wider than long, with crab-like appearance and locomotion, i.e. moving sideways. Rosenfield (1967) studied the naupliar development among Diosaccidae and published the naupliar development of Paramphiascella fulvofasciata Rosenfield, Coull, 1974. Dahms (1986, 1987) subsequently compared populations of Paramphiascella fulvofasciata from Massachusetts (studied by Rosenfield) and from Helgoland.

Most peculiar are nauplii of Stenhelia, Delavalia, and Pseudostenhelia, which are the only harpacticoids known to construct and dwell in mucoid tubes (Lorenzen, 1969; Williams-Howze et al., 1987) in all developmental stages. Dahms and Bresciani (1993) gave a historical update of postembryonic research on Stenhelia, described nauplii of Stenhelia palustris, and suggested its exclusion from Diosaccidae on the grounds of its striking naupliar apomorphies. Apstein (1908) was the first author to describe the naupliar exuviae of Stenhelia, probably Stenhelia palustris, followed by Purasjoki (1945). Both authors, however, did not recognize that their specimens belong to Stenhelia. This was demonstrated later independently by Delamare-Debouteville (1960) and Bresciani (1960), who also gave the first account of the helicoidal but sideways locomotion of Stenhelia nauplii.

Por (1964) raised the taxon Melima Por, 1964 (later synonymized with Stenhelia by Wells and Rao (1987) but resurrected by Willen (2002)). He stated „The creation of the genus Melima, placed next to Stenhelia with its two subgenera brings us closer to the necessary separation of the highly peculiar Stenhelia-like Harpacticoida from the other Diosaccidae". It became clear to Dahms (1990) that nauplii provided a similar hiatus in character performances - between S. palustris - the only stenheliinid species where nauplii were known (see Dahms, Bresciani, 1993) and all diosaccid nauplii known at that time. This initiated interest in pursuing naupliar characters in this group of phylogenetically related taxa.

There are several reasons why naupliar characters have thus far been widely neglected in systematic and phylogenetic studies, e.g. in difficulties to obtain detailed information on naupliar characters, nauplii provide fewer characters than later ontogenetic instars and adults, lack of appropriate comparative data, and conflicting evidence when comparing adult and naupliar character states.

The present study provides the first description of nauplii belonging to another stenheliinid species, namely Stenhelia peniculata (Lang, 1965). This enabled us to compare naupliar characters of taxa belonging to the same 
and to different systematic rank, providing ontogenetic apomorphies for established monophyletic groups, the legitimate approach of reconstructing phylogeny.

\section{Materials and Methods}

Nauplii of Stenhelia peniculata (Lang, 1965) were collected from an intertidal mudflat in Auke Bay $\left(58^{\circ} 22^{\prime} \mathrm{N}, 134^{\circ} 40^{\prime} \mathrm{W}\right)$ with a hand-held, piston corer (2.6 cm diameter) from March, 1992 to April, 1993 (N.V. Schizas, see Schizas, Shirley, 1996). Auke Bay is a subarctic embayment with known biota and hydrography (Coyle, Shirley, 1990), approximately 19 $\mathrm{km}$ north of Juneau, Alaska. Samples were preserved in $10 \%$ buffered formalin and stained with Rose Bengal to facilitate sorting. The sediment samples were washed through a $500 \mu \mathrm{m}$ sieve to exclude macrofauna and a $39 \mu \mathrm{m}$ sieve to retain meiofauna. Specimens designated for light microscopical study were fixed in 5\% formalin and embedded in W15 (C. Zeiss company). Mounting and further treatments of fixed naupliar stages are described by Dahms (1990, $2004 b$ ). As the nauplius eye soon loses colour and shape in the embedding medium, it was omitted in the drawings. Measurements are given from the frontal portion of the naupliar shield to the caudalmost protrusion of the hind-body (length) and widest lateral tips of the naupliar shield (width); only the specimens drawn were considered for the lengths measurements. Otherwise, 2-5 specimens per stage were used for the investigation of stage-specific variability. Species identification was done with the aid of Lang's $(1948,1965)$ monographs if not stated otherwise.

Abbreviations used:

A1 - first antenna; A2 - second antenna; Enp — endopod; Exp — exopod; Cur — caudal ramus; Md - mandible; Mx1 - first maxilla; N I, II ... - nauplius I, II etc.

Аббревиатура:

A1 - первая антенна; А2 - вторая антенна; Enp — эндоподит; Exp экзоподит; Cur - каудальная ветвь; Md - мандибула; Mx1 - первая максилла; N I, II ... - науплиус I, II и т.д.

\section{Description}

Individuals of all six naupliar stages are strictly benthic and move sideways. They are wider than long in shape and not pigmented except for the red eye. The cephalic shield covers the whole body including the hindbody in all naupliar stages (Figs. 1, 2).

\section{Nauplius I (Figs. 1, 3-5)}

Body length $63 \mu \mathrm{m}$, body width $108 \mu \mathrm{m}$. The body is wider than long and the cephalic shield shows lobular bulges at both lateral sides. The hindbody bears 1 seta (=the initial furca), arising from a protuberance on each caudal side and a row of short spinules in between. The almost circular labrum is furnished with hairy spinules along its lateral and distal edge. The unornamented sternal field wall arises as a lappet-like fold from under the labrum, in between the second antennae.

The first antenna is 3 -segmented. The $1^{\text {st }}$ segment is unornamented. The $2^{\text {nd }}$ segment bears 2 tiny setae, 1 tiny process between them and 1 outer distal row of spinules. The distal segment is armed with 3 setae, the outermost strong and outwardly curved, 1 aesthetasc, and 1 row of spinules, at the outer anterior distal corner (Fig. 3).

The second antenna bears a large coxa medially drawn out into a masticatory process, which widens and becomes fan-shaped distally (Fig. 4). The coxa has a proximal seta; the masticatory process bears a gnathobase at its blade-like median edge, split into 2 spiniform projections which bear 2 inner spinules and points under the labrum towards the recessed mouth opening. Between the anterior and posterior spiniform projections of the gnathobase there is a fine membrane covered with a row of spinules. The basipod bears 2 inner longer proximal and 2 shorter distal setae medially. The tubular endopod, being as long as the first exopodal segment, bears 2 median setae, 1 short terminal, stout, spinulose claw-shaped seta, 1 


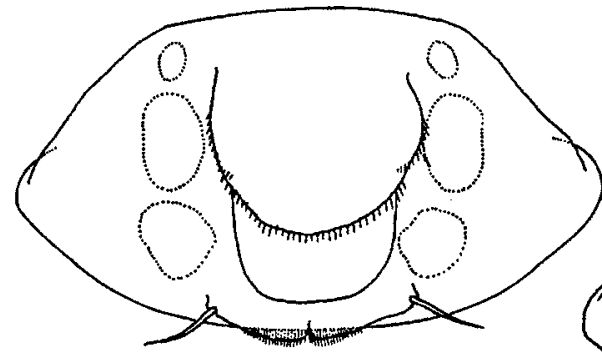

NI

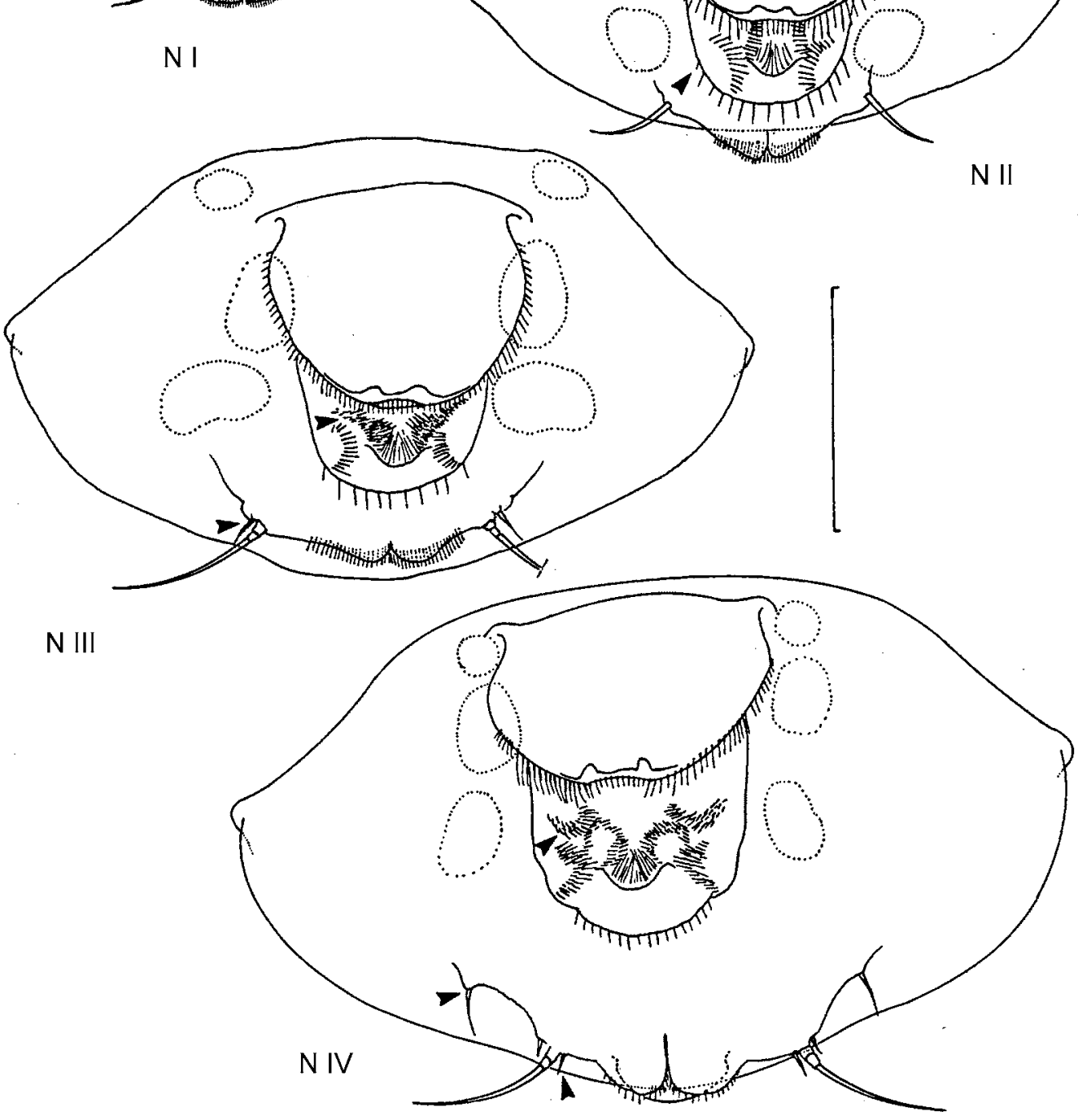

Fig. 1. Stenhelia peniculata. Naupliar stages I-IV in ventral view. Insertion area of frontal 3 pairs of appendages (=naupliar limbs) indicated by dashed lines. Arrowheads indicate new structures as compared to preceding stage. Scale bar $50 \mu \mathrm{m}$.

Pис. 1. Stenhelia peniculata. Науплиусы стадии I-IV, вид снизу. Места прикрепления передних 3 пар конечностей отмечены пунктирной линией. Стрелками обозначены новые структуры, отсутствующие у предшествующей стадии. Масштаб 50 мкм. 
taller seta on its outer terminal edge and 1 inner setule. The extended exopod is 3-segmented. The proximal segment is twice as long as the endopod. On the outer margin of the first segment, medially there is a flap-like, unornamented notched process. The shorter $2^{\text {nd }}$ segment bears 1 long spinulose seta and the $3^{\text {rd }}$ segment is armed with 1 subterminal and 2 terminal spinulose setae (Fig. 4).

The mandible is made of a short proximal portion (=initial coxa) with one setulate seta medially, a large basipod (Fig. 5). At its base the basipod is elongated into a short protrusion bearing 1 setulate seta. The surface of the basipod is furnished with a row of spinules at the inner and outer distal corner. The 1-segmented endopod arises from the first third of the inner edge of the basipod and bears 2 and another 1 stout spinulose seta, and 2 very small setae laterodistally. The exopod is 1-segmented and slightly lengthening in its first fifth. The proximal part is tubular, about 3.5 times as long as wide, and unornamented throughout the naupliar phase; it bears 1 spinulose seta in the proximal fifth of the outer edge, and, an innermost spine furnished with heavy spinules in its distal half and with a row of spinules along the outer edge up to the tip and a subterminal spinulose spine (Fig. 5).

\section{Nauplius II (Figs. 1, 3-5)}

Body length $80 \mu \mathrm{m}$, body width $130 \mu \mathrm{m}$. N II differs from $\mathrm{N}$ I in the following aspects:

Sternal field wall is ornamented with spinule rows midlength along its caudal margin; it also shows 2 short median convex rows of spinules on both lateral sides (=initial paragnaths) (Fig. 1).

The gnathobase of the antenna has a tripartite inner process (Fig. 4). Its proximal basipodal seta as long as the whole gnathobase.

The mandibular basipod bears a second seta on its inner proximal corner. There is an additional seta on the mandibular endopod. A small seta is added at the proximal outer margin of the exopod; the exopod becomes slightly Sshaped.
Nauplius III (Figs. 1, 3-5)

Body length $95 \mu \mathrm{m}$, body width $160 \mu \mathrm{m}$. N III differs from N II in the following aspects:

First antenna with 1 additional median seta on its distal segment (Fig. 1).

Antennal gnathobase bears a strong spinulose seta at base of its masticatory process (Fig. 4). Its endopod with an additional $3^{\text {rd }}$ seta proximally on its inner margin and a $3^{\text {rd }}$ seta accompanying the terminal subchelate seta at its base. The proximal portion of the first exopod segment shows a $4^{\text {th }}$ median seta midlength and a posterior $4^{\text {th }}$ seta on its distal segment.

The mandibular basipod obtains a $4^{\text {th }}$ seta at its proximal corner (Fig. 5).

Hindbody with 1 tiny additional outer seta on either side.

\section{Nauplius IV (Figs. 1, 3-5)}

Body length $110 \mu \mathrm{m}$, body width $175 \mu \mathrm{m}$. $\mathrm{N}$ IV differs from $\mathrm{N}$ III in the following aspects:

First antenna with 3 additional setae on the posterior face of its distal segment (Fig. 3).

The maxillular limb bud appears bearing a single seta (Fig. 1). There are no changes in the mandible.

Hindbody with a tiny additional inner seta between the innermost and the larger caudolateral seta (Fig. 1).

\section{Nauplius V (Figs. 2-5)}

Body length $130 \mu \mathrm{m}$, body width $200 \mu \mathrm{m}$. $\mathrm{N}$ V differs from N IV in the following aspects:

First antennae with an additional small seta posteriorly midlength on the distal segment (Fig. 3).

The antennal endopod bears a $4^{\text {th }}$ seta on its inner proximal margin proximal to the other seta (Fig. 4).

Mandibular basipod with a spiniform $5^{\text {th }}$ seta medially at its proximalmost corner. Distal exopodal portion stretched considerably (Fig. 5).

The precursor of the first maxilla becomes weakly subdivided and with a $2^{\text {nd }}$ seta $(\mathrm{Mx} 1)$. 


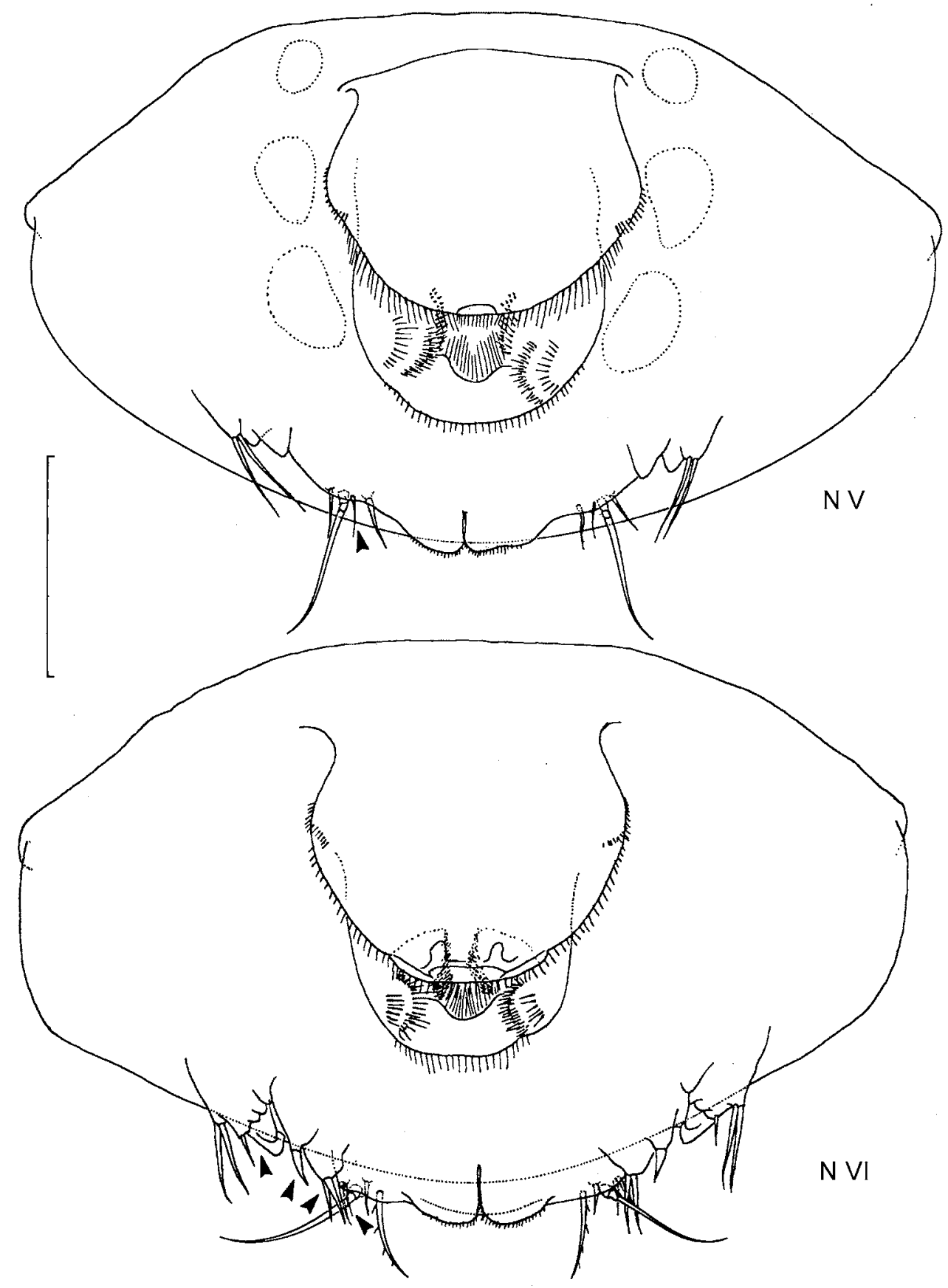

Fig. 2. Stenhelia peniculata. Naupliar stages V and VI in ventral view. Insertion area of naupliar limbs indicated by dashed lines. Arrowheads indicate new structures as compared to preceding stage. Scale bar 50 $\mu \mathrm{m}$.

Рис. 2. Stenhelia peniculata. Науплиусы стадии V и VI, вид снизу. Места прикрепления конечностей отмечены пунктирной линией. Стрелками обозначены новые структуры, отсутствующие у предшествующей стадии. Масштаб 50 мкм. 


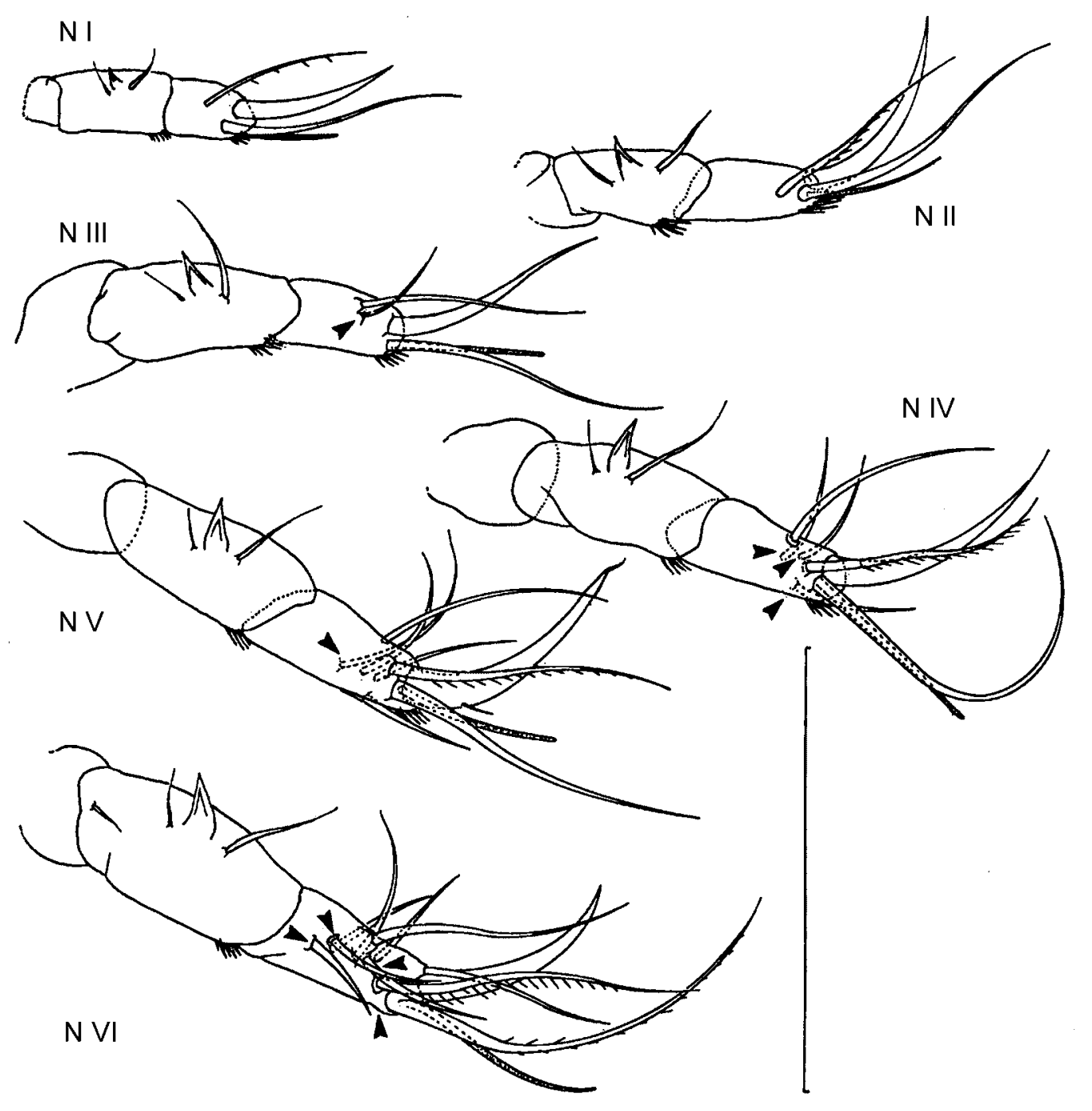

Fig. 3. Stenhelia peniculata. Development of naupliar left first antennae in anterior view. Arrowheads indicate new structures as compared to preceding stage. Scale bar $50 \mu \mathrm{m}$.

Pис. 3. Stenhelia peniculata. Развитие левой первой антенны науплиуса. Стрелками обозначены новые структуры, отсутствующие у предшествующей стадии. Масштаб 50 мкм.

There are 2 other buds of postmandibular appendages visible on both ventral sides (Fig. 2).

The flanks of the labrum are somewhat bulged. side.

Hindbody with a $4^{\text {th }}$ tiny seta on either inner

\section{Nauplius VI (Figs. 2-5)}

Body length $140 \mu \mathrm{m}$, body width $220 \mu \mathrm{m}$. $\mathrm{N}$ VI differs from $\mathrm{N} \mathrm{V}$ in the following aspects:

Distal segment of first antenna with 4 additional setae on the anterior face midlength (Fig. 3). 


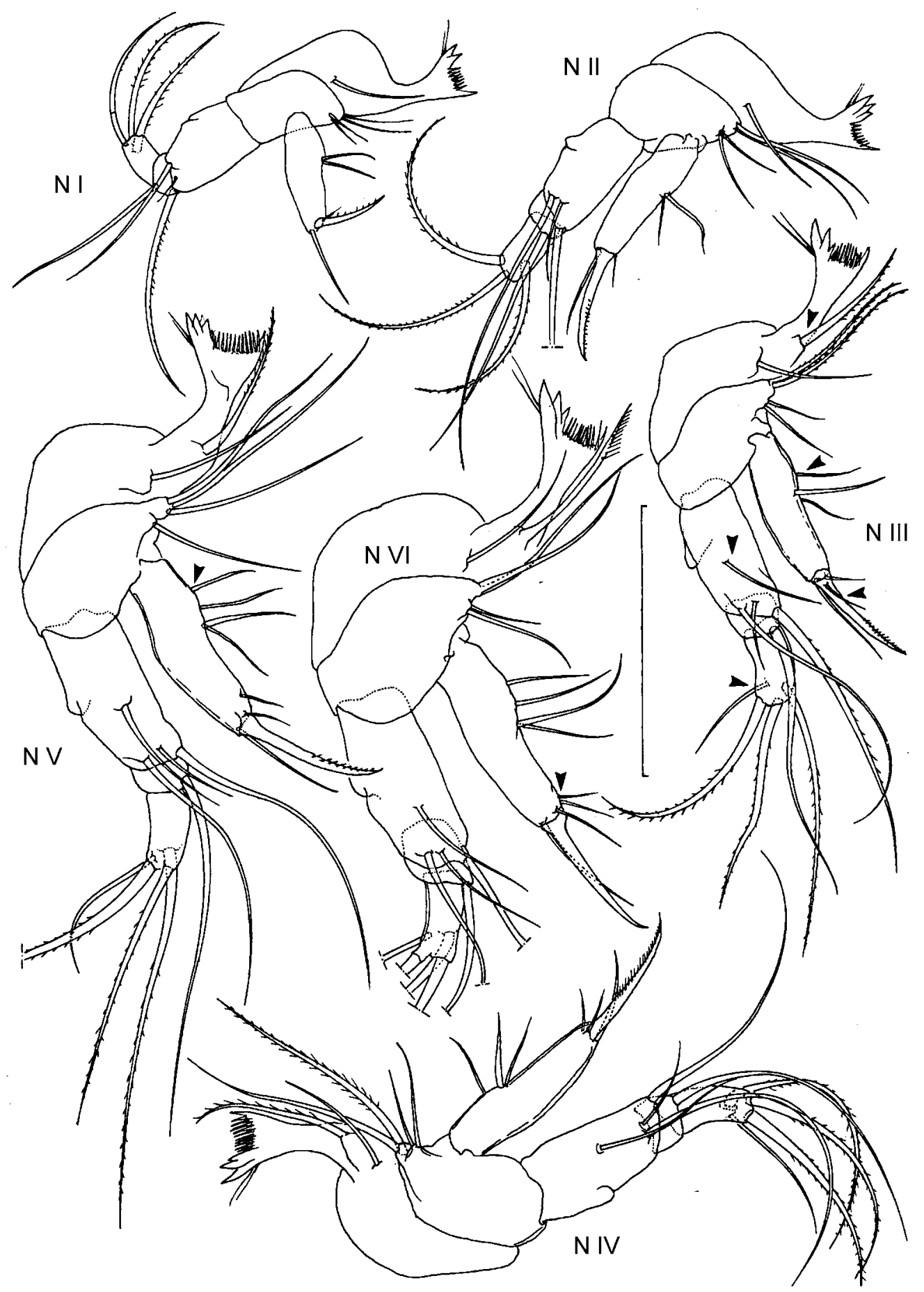

Fig. 4. Stenhelia peniculata. Development of naupliar right second antennae. Arrowheads indicate new structures as compared to preceding stage. Scale bar $50 \mu \mathrm{m}$.

Рис. 4. Stenhelia peniculata. Развитие правой второй антенны науплиуса. Стрелками обозначены новые структуры, отсутствующие у предшествующей стадии. Масштаб 50 мкм. 


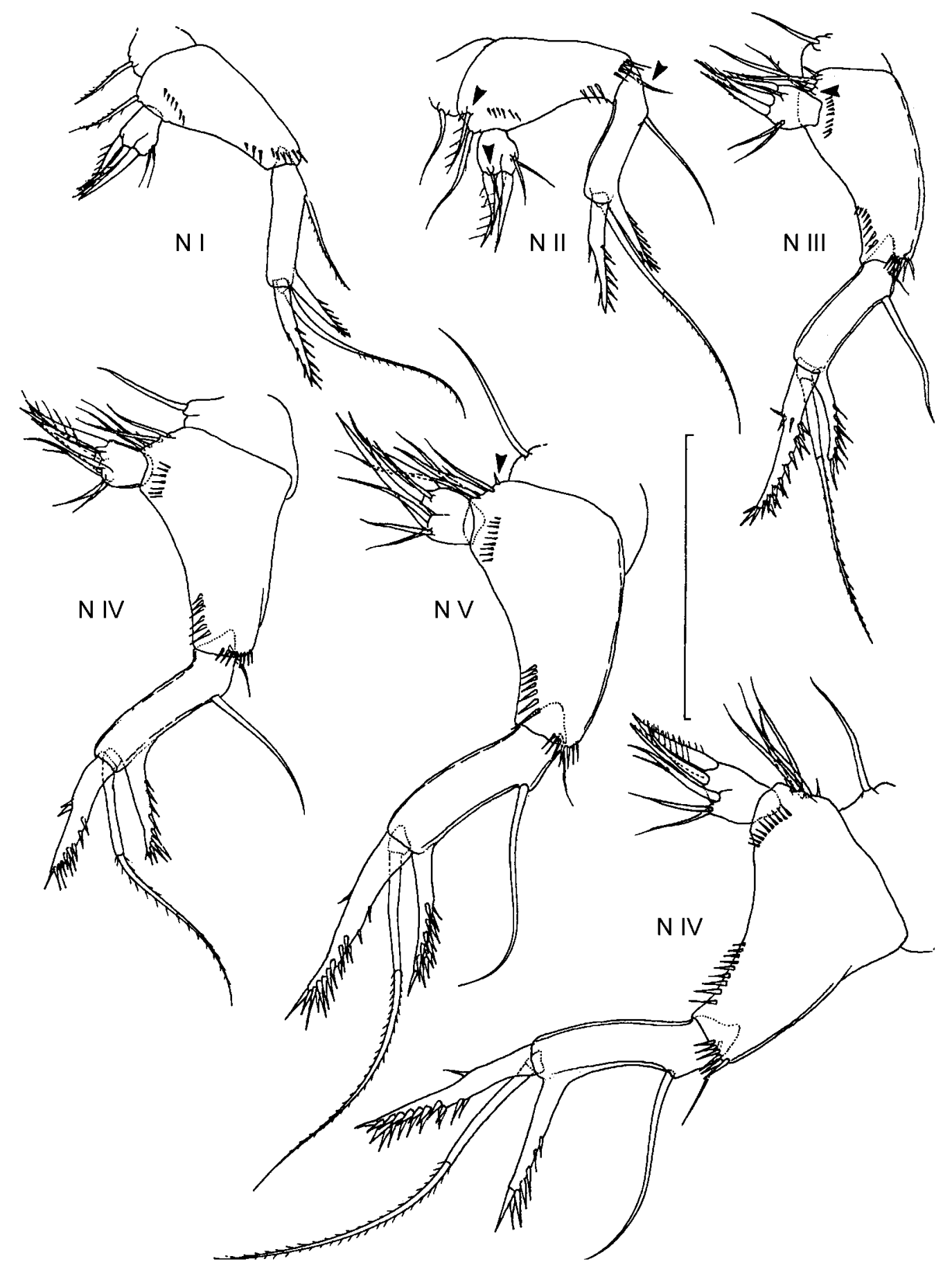

Fig. 5. Stenhelia peniculata. Development of naupliar left mandible. Arrowheads indicate new structures as compared to preceding stage. Scale bar $50 \mu \mathrm{m}$.

Рис. 5. Stenhelia peniculata. Развитие левой мандибулы науплиуса. Стрелками обозначены новые структуры, отсутствующие у предшествующей стадии. Масштаб 50 мкм. 
There is a small $5^{\text {th }}$ seta terminally on the endopod of the second antenna (Fig. 4).

Mandibular endopod expanded, now revealing its 2-segmented nature; basipodal projection enhanced; coxa' still a lobe with 1 styletlike seta.

The precursor of the first maxilla develops a $3^{\text {rd }}$ inner seta. The inner edge with enditic lobes; 1 seta on the endopod, 1 seta on the presumptive exopod (Fig. 2).

There are 4 lobular precursors of postmandibular appendages developed on both lateral sides. It is difficult to identify the anterior two unarmed limb-buds. We assume, however, that these represent the first maxilla and maxilliped precursor. As usual also in other copepods, the first two swimming legs are indicated at the 6th nauplius stage. Hence, we interpret the lobe with 1 seta to correspond to leg 1 , and further caudally, the lobe with 2 setae to correspond to leg 2 (Fig. 2), while the second maxilla is missing.

Key for the naupliar stages of Stenhelia peniculata

1. Hindbody with 1 seta on each side .. 2

- Hindbody with 2 setae on each side .... N III - Hindbody with 3 setae on each side; bud of first maxilla with 1 seta N IV

- Hindbody with at least 4 setae on either side; first maxilla bud bearing 2 or more setae..... 3 2. Mandibular basis with 1 seta at the proximal inner corner; exopod with 1 distal seta ..... N I - Mandibular basis with 2 setae at the proximal inner corner, exopod with 1 proximal seta and 1 seta halfway down the margin N II 3.Hindbody with 4 setae on either side; buds of less than 3 postmandibular limbs present ......

$\mathrm{N} \mathrm{V}$

- Hindbody with 5 setae on either side; buds of 3 postmandibular limbs present N VI

\section{Discussion}

As hypothesized by Willen (2002) who based her arguments on adult characters, probably neither "Stenhelia“" nor „St. Stenhelia“ and „St. Delavalia“ are monophyletic. The „foreshortened naupliar habitus" used to unite the Diosaccidae and Stenheliinae as sistergroups is problematical if the Diosaccinae as well as in the Miraciinae the plesiomorphic ,elongate habitus". The Miraciinae and not the Stenheliinae have been placed as the sistergroup of the Diosaccinae in the system of Willen (2000).

Willen (2000) reaffirmed the monophyly of the Stenheliinae Brady, 1880, by using adult autapomorphies alone. Willen (2000) demonstrated that the Stenheliinae show the autapomorphies defining the Thalestrioidea and Diosaccidae, respectively. Two alternative explanations can be deduced from this:

1. because of their special non-homologous realization of the male swimming leg 2 endopod, the Stenheliinae have to be removed from both Thalestrioidea and Diosaccidae, which would have the consequence, that all autapmorphies of the Thalestrioidea and Diosaccidae would have developed at least twice independently,

or alternatively,

2. have evolved convergently within the Stenheliinae, of which the monophyly is well supported, and could be interpreted as additional autapomorphies of this taxon. The latter alternative was accepted by Willen (2000) stating that there is no evidence to assign the Stenheliinae to any other taxon of the Thalestridimorpha.

The traditional subgeneric division of Stenhelia was abandoned by Mu and Huys (2002) since both subgenera, Stenhelia (Stenhelia) and Stenhelia (Delavalia), are polyphyletic taxa. They tentatively upgraded the latter to generic rank pending a phylogenetic analysis of the Stenheliinae. The genus Stenhelia was restricted to a core group of species formerly allocated to the subgenus Stenhelia (Stenhelia), including $S$. gibba, S. proxima, S. curviseta, $S$. divergens, $S$. peniculata, $S$. pubescens and two new species, $S$. sheni and S. taiae described from the Bohai Sea. The genus Beatricella, erroneously considered a junior objective synonym of Stenhelia, was reinstated to accommodate $S$. aemula as the type species. The problematic $S$. asetosa was transferred to a new genus Anisostenhelia. S. xylophila was designated as the type of a new genus Hicksia. 
Table 1. Naupliar apomorphies of Stenhelia peniculata (present study) and S. palustris - cf. Dahms and Bresciani (1993). Respective apomorphic character states are highlighted in bold throughout - the plesiomorphic character state not in bold.

Таблица 1. Апоморфии науплиусов Stenhelia peniculata (оригинальные данные) и S. palustris - по Dahms, Bresciani (1993). Апоморфные состояния признаков выделены жирным шрифтом, плезиоморфные состояния без выделения.

\begin{tabular}{|c|c|c|}
\hline Structure & S. peniculata & S. palustris \\
\hline$\overline{\mathrm{A} 1}$ & - $3^{\text {rd }}$ segment: 3 medial setae $(\mathrm{N}$ III) & - $3^{\text {rd }}$ seg.: 2 medial setae (N III) \\
\hline Md & $\begin{array}{l}\text { - endopod with } 3 \text { setae on } \\
\text { outer lateral field (N VI) }\end{array}$ & - endopod with 4 setae on outer lateral field ( $\mathrm{N} \mathrm{VI)}$ \\
\hline & - no spinulation on exopod (N I-VI) & $\begin{array}{l}\text { - strong denticuliform spinulation on exopod ( } N \\
\text { II-III - being reduced at N IV-VI) }\end{array}$ \\
\hline Mx 1 & - armature: 3 setae ( $\mathrm{N} \mathrm{VI)}$ & - armature: 2 setae (N V-VI) \\
\hline
\end{tabular}

Table 2. Naupliar apomorphies of Stenhelia (as evidenced from Stenhelia palustris and Stenhelia peniculata) and Pseudostenhelia (as evidenced from Pseudostenhelia wellsi - cf. Dahms and Fleeger (submitted). Respective apomorphic character states are highlighted in bold throughout - the plesiomorphic character state not in bold.

Таблица 2. Апоморфии науплиусов Stenhelia (на основании данных по развитию Stenhelia palustris и Stenhelia peniculata) и Pseudostenhelia (на основании данных по Pseudostenhelia wellsi - по Dahms, Fleeger (submitted). Апоморфные состояния признаков выделены жирным шрифтом, плезиоморфные состояния без выделения.

\begin{tabular}{lll} 
Structure & \multicolumn{1}{c}{ Stenhelia } & \multicolumn{1}{c}{ Pseudostenhelia } \\
\hline A1 & - terminal seta as long as $3^{\text {rd }}$ segment & - terminal seta 3 times as long as $3^{\text {rd }}$ seg. \\
A2 & - endopod - middle 4 setae of regular size & - endopod - middle 2 of 4 setae much longer \\
Md & - exopod proximal seta long & - exopod proximal seta much reduced \\
& - enp. outer lateral field with 1 long seta & - endopod outer lateral field with 3 long setae \\
Cur & - the inner caudal seta one half the & - 2 caudal setae \\
& length than the outer caudal setae &
\end{tabular}

Table 3. Naupliar apomorphies of Stenheliinae (as evident from Stenhelia palustris, S. peniculata, Pseudostenhelia wellsi) and Diosaccinae (as evident from all foreshortened and elongate naupliar forms known, as described and discussed by Dahms (1990)). The respective apomorphic character state is highlighted in bold - the plesiomorphic character state not in bold.

Таблица 3. Апоморфии науплиусов Stenheliinae (на основании данных по развитию Stenhelia palustris, Stenhelia peniculata и Pseudostenhelia wellsi) и Diosaccinae (на основании данных по развитию укороченных и удлиненных форм, описанных и рассмотренных Dahms (1990)). Апоморфные состояния признаков выделены жирным шрифтом, плезиоморфные состояния без выделения.

\begin{tabular}{|c|c|c|}
\hline Structure & $\begin{array}{c}\text { Stenheliinae } \\
\end{array}$ & Diosaccinae \\
\hline Body & $\begin{array}{l}\text { - the lateral edge of the nauplius shield } \\
\text { bears protuberances on each side }\end{array}$ & - no protuberances \\
\hline A2 enp & $\begin{array}{l}\text { - the masticatory process is peculiarly } \\
\text { fan-shaped distally }\end{array}$ & - never fan-shaped \\
\hline A2 exp & $\begin{array}{l}\text { - the antennal exopod is strongly developed, } \\
\text { 3-segmented and upwardly curved }\end{array}$ & $\begin{array}{l}\text { - never strongly developed, 4-seg- } \\
\text { mented, not upwardly curved }\end{array}$ \\
\hline Md & $\begin{array}{l}\text { - the whole mandible is of unique shape and } \\
\text { orientation (basis, endopod and exopod) }\end{array}$ & - not so \\
\hline Md basis & - the mandibular basis bears 2 setae at $\mathrm{N} \|$ & - bears 1 seta from $N$ II - N IV \\
\hline Md enp & $\begin{array}{l}\text { - the posterolateral field of the mandibular endopod } \\
\text { bears a remarkably strong, inner spinulose spine }\end{array}$ & - not so \\
\hline Md exp & - the 3 distal exopodal setae are of unique structure & - not so \\
\hline
\end{tabular}


As shown by Dahms (1990), two groups of distinct naupliar forms occur within the Diosaccinae, foreshortened and elongate ones. Compared to those representatives of the $\mathrm{Di}$ osaccinae sensu Willen (2000) with foreshortened nauplii, peculiarities of the nauplii of $S$. palustris, S. peniculata, and Pseudostenhelia wellsi, have not been given adequate attention as yet. Although the nauplii of the latter three taxa are much wider than long and move sideways as do the foreshortened nauplii of certain diosaccid taxa, they exhibit several unique characters in relation to diosaccinid nauplii in general. Some peculiarities of larvae belonging to S. palustris and nauplii belonging to Diosaccinidae have been discussed by Dahms and Bresciani (1993). Stenheliinid nauplii exhibit a number of morphological peculiarities so far unknown from other oligoarthran harpacticoids (Table 3) (cf. Dahms 1990) and crustacean nauplii ( $c f$. Dahms 2004a) - which are interpreted as evolutionary novelties. We hypothesize, therefore, that these naupliar peculiarities common to both, Stenhelia and Pseudostenhelia, are autapomorphies of the Stenheliinae to those of the Diosaccinae (Table 3) with all other known oligoarthran nauplii as an outgroup. As for the habitus, the extremely foreshortened shape and the lateral protuberances of the naupliar cephalic shield are unknown elsewhere in the Harpacticoida and provide a synapomorphy for both taxa, Pseudostenhelia and Stenhelia. As for the Stenheliinae, the first antenna bears a peculiar protuberance on the distal third of the second segment. Its distal segment bears a peculiarly notched inner distal seta. The second antennal exopod bears a flaplike outer protuberance on its first segment. The shape of the stenheliinid mandible is unique with its laterodistally elongated basipod, and the strongly sclerotized exopod with peculiar spiniform setae on its distal segments. These special setae may serve as adjustments for performing vigorous crawling strokes. Although nauplii of Stenhelia (D.) spp. and Pseudostenhelia wellsi are much wider than long and are able to move sideways as the group of foreshortened diosaccid nauplii does, they exhibit a remarkable number of evolutionary novelties (Table 2).
Naupliar characters are sufficiently different at different systematic levels as shown above using $S$. peniculata as a model and are useful for phylogenetic analysis. S. peniculata shows several naupliar characters which are different to those of S. palustris beyond intraspecific variability. Both species of Stenhelia are demarcated from Pseudostenhelia by even more pronounced and unique naupliar apomorphies. These apomorphic characters in outgroup-comparison to other harpacticoid nauplii confirm the distinct status of Stenhelia and Pseudostenhelia belonging to different monophyla among the Stenheliinae. Also, on wider phylogenetic level, naupliar differences provide apomorphies for Stenheliinae on the one hand and Diosaccinae on the other.

It has to be considered, however, that nauplii are known only from two of the 8 valid species of Stenhelia, 51 species in Delavalia, 5 species in Melima and another 9 in various other stenheliid genera. The situation is similar in the Diosaccinae, being one of the largest taxa within the Oligoarthra concerning the number of species. One has to be aware that statements on ,autapomorphies" of these higher taxa based on larval characters are based on a small database.

\section{Acknowledgements}

This evaluation would not have been feasible without the numerous contributions on naupliar development by other researchers; to name only: Tagea Björnberg (Săo Paulo), Geoff A. Boxshall (London), Frank Ferrari (Washington D.C.) Geoffrey Fryer (Ambleside), Mark J. Grygier (Lake Biwa), Jens T. Høeg and Jørgen Olesen (both Copenhagen), late Tatsunori Itô (Kyoto), Kunihiko Izawa (Mie), Horst K. Schminke (Oldenburg), and Dieter Waloszek (Ulm). Critical amendments on the manuscript by three referees are particularly acknowledged. The authors, however, are fully responsible for the contents of this contribution. This study was funded in part by the DFG (German National Science Foundation) - HUD being the principal investigator (Da256/7-1; Da 256/101) and DAAD (A/99/09723). 


\section{Literature}

Apstein C. 1908. Nauplius pagurus. In Die Beteiligung Deutschlands an der Internationalen Meeresforschung // IV/V Jahresbericht. Berlin. P.55-58.

Ax P. 1987. Systematik in der Biologie. UTB, G. Fischer Verlag Stuttgart. P.1-181.

Bresciani J. 1960. Some features of the larval development of Stenhelia (Delavalia) palustris Brady, 1868 (Copepoda, Harpacticoida) // Videnskab. Meddelels. dansk naturh. Foren 123. P.241-249.

Coyle K.O., Shirley T.C. 1990. A review of fisheries and oceanographic research in Auke Bay, Alaska and vicinity // Zeimann, D. A. and K. W. Fulton-Bennett, (ed.). APPRISE-Interannual variability and fisheries recruitment The Ocean Institute. Honolulu, HI. P.173.

Dahms H.-U. 1986. Zur Biologie von Paramphiascella fulvofasciata (Copepoda, Harpacticoida) // Helg. Meeresunters. Vol.40. P. 267-277.

Dahms H.-U. 1987. First record of Paramphiascella fulvofasciata Rosenfield \& Coull, 1974 (Copepoda, Harpacticoida) from the German Bight // Crustaceana. Vol.52. P.218-219.

Dahms H.-U. 1990. Naupliar development of Harpacticoida (Crustacea, Copepoda) and its significance for phylogenetic systematics // Mikrofauna Marina. Vol.6. P.169-272.

Dahms H.-U. 1993. Copepodid development in Harpacticoida (Crustacea, Copepoda) and its significance for phylogenetic systematics // Mikrofauna Marina. Vol.8. P.195-245.

Dahms H.-U. 2004a. Postembryonic apomorphies proving the monophyletic status of the Copepoda // Zoological Studies (Taipei). Vol. 43. No.2. P.446-453.

Dahms H.-U. 2004b. Exclusion of the Polyarthra from the Harpacticoida and its reallocation as an underived podoplean taxon of the Copepoda (Arthropoda, Crustacea) // Invertebrate Zoology. Vol.1. No.1. P.29-51.

Dahms H.-U., Bresciani J. 1993. Naupliar development of Stenhelia (D.) palustris (Copepoda, Harpacticoida) // Ophelia. Vol.37. P.101-116

Dahms H.-U., Fleeger J.W. Naupliar development of Pseudostenhelia wellsi Coull and Fleeger, 1977 (Copepoda, Harpacticoida) and the evolution of sidewaylocomotion // J. Crust. Biol. (submitted).

Delamare-Deboutteville C. 1960. Biologie des eaux souterraines littorales et continentales. Hermann, Paris. P.1-740.

Lang K. 1948. Monographie der Harpacticiden I und II. Reprint Otto Koeltz Science Publ., Königstein, W-
Germany. P.1-1682.

Lang K. 1965. Copepoda Harpacticoida from the Californian Pacific Coast I + II. Kungl. Svenska Vetenskapsakademiens Handlinger // Fjärde Serien Bd. Vol.10. No.2. P.1-560.

Lorenzen S. 1969. Harpacticoiden aus dem lenitischen Watt und den Salzwiesen der Nordseeküste // Kieler Meeresforsch. Vol.25. No.1. P.215-223.

Mu F.H., Huys R. 2002. New species of Stenhelia (Copepoda, Harpacticoida, Diosaccidae) from the Bohai Sea (China) with notes on subgeneric division and phylogenetic relationships // Cah. Biol. Mar. Vol.43. P.179206

Por F.D. 1964. A study of the Levantine and Pontic Harpacticoida (Crustacea, Copepoda) // Zool. Verh. Rijksmus. Natuurl. Hist. Leiden. Vol.64. P.1-128.

Purasjoki K.J. 1945. Quantitative Untersuchungen über die Mikrofauna des Meeresbodens in der Umgebung der Zoologischen Station Tvärminne an der Südküste Finnlands // Soc. Sci. Fenn. Commentat. Biol. Vol.9. No.14. P.1-24

Rosenfield D.C. 1967. The external morphology of the developmental stages of some diosaccid harpacticoid copepods (Crustacea) from the Massachusetts-Bay // Ph. D. thesis, Boston University. P.1-307.

Rosenfield D.C., Coull B.C. 1974. Adult morphology and larval development of Paramphiascella fulvofasciata n. sp. (Copepoda, Harpacticoida) // Cah. Biol. Mar. Vol.15. No.2. P.295-317.

Schizas N.V., Shirley T.C. 1996. Seasonal changes in structure of an Alaskan intertidal meiofauna assemblage // Mar. Ecol. Progr. Ser. Vol.133. P.115-124.

Walossek D. 1993. The upper Cambrian Rehbachiella and the phylogeny of Branchiopoda and Crustacea // Fossils Strata. Vol.32. P.1-202.

Wells J.B.J., Rao G.C. 1987. Littoral Harpacticoida (Crustacea: Copepoda) from Andaman and Nicobar Islands // Mem. Zool. Surv. India. Vol.16. P.1-385.

Willen E. 2000. Phylogeny of the Thalestridimorpha Lang, 1944 (Crustacea, Copepoda) // Cuvillier Verlag, Göttingen. P.1-233.

Willen E. 2002. Notes on the systematic position of the Stenheliinae (Copepoda, Harpacticoida) within the Thalestridimorpha and description of two species from Motupore Island, Papua New Guinea // Cah. Biol. Mar. Vol.43. P.27-42.

Williams-Howze J., Silverman H., Fleeger J.W. 1987. Internal morphology related to tube-building in the meiobenthic copepod Pseudostenhelia wellsi // J. Crust. Biol. Vol.7. P.171-187. 